\section{Trilinear Chart of Nuclides}

THE enormous amount of scientific data coming from laboratories of many countries is useless unless the information reaches the user as quickly as possible, and it must be in a form convenient enough to become popular with the searcher of information. In the case of the basic properties of nuclei large tables have been very useful, the most widely spread design being that due to W. H. Sullivan, which is based on a trilinear chart. In view of the continuous increase of information and the constant improvement of data already known, the sponsor of Sullivan's tables, the U.S. Atomic Energy Commission, is now offering a service to keep the collection up to date. This is done by replacing the hexagons making up the table with new ones containing the improved information. The first two sheets of replacements contain 45 and 49 hexagons, respectively, ready to be stuck over the old ones. The data reported are: isotopes, isobars, isotones, isodiapheres, beta line of stability, atomic mass, isotopic abundance, alpha and beta stability or instability, genetic relationships, production modes, disintegration modes, nuclear isomerism, radiation energy and intensity, half-life, branching ratios, per cent internal conversion, fission yield, whole element and isotopic cross-sections, spin, mannetic moment, and degree of certainty of $A$ and $Z$ assignment. The issue runs to 25,000 prints. Revision sheets can be obtained on a subscription basis from the Superintendent of Documents, U.S. Government Printing Office, Washington 25, D.C.

\section{The International Academy of Management}

Ax a recent meeting in Athens of the Executive Committe of the International Committee for Scientific Management, Mr. John Ryan, vice-chairman of the British Institute of Management, chairman of its International and Information and Research Committees, and vice-chairman of Metal Box Co., Ltd., was one of the eight new Fellows elected to the International Academy of Management. Nominees for membership were submitted from the twenty-nine countries of the International Committee and, among others elected, were Gaston Berger of France, Peter F. Drucker of the United States, Hugo de Haan of Austria, Bernhard Hellern of Norway, Theodore Limperg of Holland, E. Hans Mahler of Switzerland and Harold B. Maynard of the United States. The Academy was created by the International Committee in November 1958, for the purpose of "stimulating and honouring distinguished personalities for their contributions to the field of scientific manage. ment". One of the first activities of the Academy will be the selection of a prize paper to be read at the twelfth World Congress on Management being held in Australia during Fobruary 22-March 4, 1960.

\section{Symposium on Geochemistry}

A symposium on geochemistry organized by the Commission on Geochemistry of the International Union of Pure and Applied Chemistry will be held in Göttingen, Germany, on August 21 and 22, to be followed by two days field exeursions. The topics for discussion at the Symposium are : stable nuclides in geochemistry; long-lived radionuclides in natural systems ; geochemistry of the hologens ; geochemical aspects of life on earth. Further information can be obtained from Prof. C. W. Correns, SedimentPetrographisches Institut, Göttingen, Lotzestrasse 13.

\section{Announcements}

Dr. J. S. Anderson, professor of inorganic and physical chemistry in the University of Melbourne, has been appointed director of the National Chemical Laboratory, Teddington, in succession to Dr. D. D. Pratt, who is retiring.

The Dr. W. S. Bruce Memorial Prize for 1958, commemorating Dr. W. S. Bruce, the Scottish explorer and scientific investigator in polar regions, has been awarded to Dr. Hal Lister, Department of Geography, King's College, Newcastle upon Tyne, for his glaciological work with the 1957-58 Transantarctic Expedition. The committee of award is appointed by the Royal Physical Society of Edinburgh, the Royal Scottish Geographical Society and the Royal Society of Edinburgh.

Messrs. Pfizer, Ltd., the Kent manufacturing chemists, have awarded a university scholarship for science worth $£ 370$ per annum to Miss Penny Howard, of Abingdon, Berkshire, and one for chemistry worth $£ 465$ per annum to George Sayce, of Hampton Hill, Middlesex.

The Plant Phenolics Group is to hold an International Symposium on "Humic Acid" in the Department of Chemistry, University College, Dublin, on September 10 and 11. Further information can be obtained from the honorary secretary, Dr. T. Swain, Low Temperature Research Station, Downing Street, Cambridge.

A Conference on Ion Exchenge will be held at the Mountain View Hotel, Gatlinburg, Tennessee, during September 7-11, under the sponsorship of the Oak Ridge National Laboratory. Further information can be obtained from Wm. Rieman, III, Ralph G. Wright Laboratory, Rutgers, The State University, New Brunswick, New Jersey.

The annual meeting of the Electron Microscope Society of America will be held during September 9-12 in Columbus, Ohio, at the Ohio State University, when a symposium is to be arranged on "Contribution of Electron Microscopy of Viruses and Cells to the Problem of Cancer". Further information can be obtained from the secretary of the Society, D. Maxwell Teague, Chrysler Corporation, P.O. Box 1118, Detroit 31, Michigan.

Commission I of the International Institute of Refrigeration will be holding a conference in Copenhagen during August 19-26 as part of the Tenth International Congress of Refrigeration. The following topics will be discussed : applications of lowtemperature techniques in nuclear physics; mechanical properties of metals at low temperatures; thermometry ; industrial problems in connexion with the liquefaction and distillation of gases ; equation of state of mixtures; fluids under high pressure; transport phenomena in gases, liquids and solids; other problems of the application of very low temperatures in industry. Further information can be obtained from Prof. A. Van Itterbeek, Naamse. straat 73, Louvain, Belgium.

ERratum. In the article entitled "Reaction of some Silicates with Chelating Agents", by Dr. D. A. Sutton, M. D. Middleton and R. A. F. Body, pub. lished in Nature of January 10, p. 99, in Fig. 1 "Process 1" should read "Process 2" and vice versa. 